\title{
DETERMINATION OF IMPURITIES IN ICE-CORES FORM THE JUNGFRAU-JOCH BY NEUTRON ACTIVATION ANALYSIS
}

\author{
A. WYTTENBACH, ${ }^{*}$ R. RAUTER,* B. STAUFFER, ** \\ U. SCHOTTERER ** \\ ${ }^{*}$ Eidg, Institut für Reaktorforschung CH-5303 Würenlingen (Switzerland) \\ **Physikalisches Institut, Universität Bern, CH-3000 Bern (Switzerland)
}

(Received November 15, 1976)

\begin{abstract}
An ice-core of $4 \mathrm{~m}$ length was drilled at the Jungfraujoch. It was divided into 18 sections and analyzed for solid and dissolved material by neutron activation analysis using nondestructive counting as well as chemical group separations. The solid material was identified as stone dust. Part of the dissolved material seems to originate from dissolved limestone, whereas many elements can not be accounted for by this hypothesis and must be due to atmospheric fallout.
\end{abstract}

\section{Introduction}

Studies of the composition of aerosols and of atmospheric precipitations have proved a valuable tool to determine the purity of our atmosphere, and these studies are rapidly increasing in number. However, nearly all of these investigations bear only on the present day situation. In order to find any long term changes, it would be highly desirable to compare the present composition with values of the past. Unfortunately reliable analytical data exist only for the last decade or so. However it was postulated that a record of past atmospheric precipitations going back many hundreds of years is kept in ice and is therefore available for analysis with present day methods. Thus MUROZUMI et al. ${ }^{1}$ analyzed ice samples almost 3000 years old from the Antarctic continent and from Greenland and found a sharp rise in the content of $\mathrm{Pb}$ after 1940. Generally analysis of ice samples from Antarctica was much stimulated by the international expeditions to this continent.

Contrary to north and south polar ice sheets, the glaciers of the temperate zone have not been extensively surveyed as to the purity of the ice. This may be due partly to the fact that the situation in temperate zone glaciers is complicated by possible melting processes in summer and by the proximity of dust emitting bare rock formations. It was the aim of the present work to furnish analytical data for 


\section{A. WYTTENBACH et al.: DETERMINATION OF IMPURITIES}

a temperate zone glacier which would determine whether information similar to that in polar ice sheets is also contained in such glaciers. The analyses covered a wide range of elements including heavy metals and those likely to be of marine and of dust origin. All analyses were done by neutron activation.

\section{Experimental}

\section{Collection of samples}

Samples were taken in April 1974 at the Jungfraujoch (Switzerland) at an altitude of $3470 \mathrm{~m}$ with a teflon coated SIPRE core auger. The ice core has a length of $4 \mathrm{~m}$ and a diameter of $7.5 \mathrm{~cm}$. It was packed into a polyethylene hose and kept frozen at $-18^{\circ} \mathrm{C}$ until the time of analysis. A length of $4 \mathrm{~m}$ would correspond to an undisturbed accumulation of 3 years. However subsequent analysis for ${ }^{3} \mathrm{H}$ revealed that the ice was probably older than 30 years and that there was severe intrusion of recent water by melting processes. ${ }^{2}$

\section{Preparation of samples}

The method chosen for the preparation of the samples were influenced by several considerations:

(1) It is known that ice from glaciers contains inclusions of solid particles. Although some workers do not take care to remove solid material from ice ${ }^{1,3}$ or from river water, ${ }^{4}$ we thought this indispensable. Since we wanted to determine short lived activities such as ${ }^{28} \mathrm{Al},{ }^{52} \mathrm{~V},{ }^{49} \mathrm{Ca}$ and ${ }^{38} \mathrm{Cl}$, this separation had to be made prior to the irradiation. This in turn meant that irradiation of the entire ice core, although desirable from the point of view of blanks, was not feasible.

(2) The concentration of the elements in the alpine ice were not known even as to their order of magnitude. They were estimated to be between the concentration of polar ice ( $\mathrm{Na} 20 \mathrm{ppb}$, total solids $0.1 \mathrm{mg} / \mathrm{kg})^{1}$ and of English rain $(\mathrm{Na}$ $1340 \mathrm{ppb}$, total solids $\gg 4 \mathrm{mg} / \mathrm{kg}$ ). ${ }^{5}$ It was anticipated that $\mathrm{Na}$ would be one of the most abundant elements and that most other elements would be in the subppb region. This in turn implies points 3 to 5 .

(3) The blank problem will be severe.

(4) In order to achieve the necessary sensitivity, sample size must be several $100 \mathrm{~g}$ of ice.

(5) The anticipated dominance of ${ }^{24} \mathrm{Na}$ over other medium lived activities necessitates some chemical separations after the irradiation.

Taking these points into consideration, the following working scheme for the preparation of the samples for irradiation was adhered to: 


\section{A. WYTTENBACH et al.: DETERMINATION OF IMPURITIES}

(1) Core sections of $10-20 \mathrm{~cm}$ length with a weight of 400 to $800 \mathrm{~g}$ were melted in an all quartz apparatus. The first $50 \mathrm{ml}$ were discarded in an effort to remove any surface contamination of the ice that might have come from the drilling operation.

(2) The remainder of the water was filtered in the same all quartz apparatus through an $8 \mu$ and a $0.1 \mu$ membran filter (Sartorius SM 11301 and SM 11309 , diameter $25 \mathrm{~mm}$ ) in order to remove any solid material.

(3) To the filtered water $200 \mathrm{mg}$ of very pure $\mathrm{NH}_{4} \mathrm{NO}_{3}$ was added and the water was shell frozen in a 41 round bottom pyrex flask. The $\mathrm{NH}_{4} \mathrm{NO}_{3}$ was added to make possible the subsequent handling of the very small amounts $(\sim 1 \mathrm{mg})$ of the freeze-dried material.

(4) Two samples at a time were freeze-dried over a period of $36 \mathrm{hrs}$ to a constant pressure of $7 \cdot 10^{-6}$ bar.

(5) The flasks were removed to an airtight glove box and the solid contents transferred to especially clean polyethylene irradiation containers and then weighed.

Special experiments with radioactive and with activable tracers were done to check if this procedure allows the complete recovery of material originally dissolved in the water. The following ions (in amounts between 0.1 and $10 \mu \mathrm{g}$ ) were found to give recoveries between 0.95 and 1 from $500 \mathrm{ml}$ of water: $\mathrm{Al}, \mathrm{K}, \mathrm{Ca}, \mathrm{Sc}, \mathrm{Mn}$, $\mathrm{Co}, \mathrm{Zn}, \mathrm{Cd}, \mathrm{Sb}, \mathrm{Eu}$. This is in good agreement with other investigations. ${ }^{6}$ The two elements which showed low recoveries $(0.5 \pm 0.1)$ were $\mathrm{Cl}$ and $\mathrm{Br}$. This fact must be due to the slight acidity of our samples (which had a pH of 5.5 in correspondence to the $\mathrm{pH}$ of the ice samples), since the recovery of $\mathrm{Br}$ from neutral solutions is reported to be 1 and the recovery of I from solutions of $\mathrm{pH} 1.5$ to be $(0.7 \pm 0.2)^{6}$

\section{Activation, chemical separation and measurement}

The freeze-dried residue was irradiated in the SAPHIR reactor for 5, 12 and 510 minutes, corresponding to integrated neutron doses of $2 \cdot 10^{15}, 3 \cdot 10^{16}$ and $2 \cdot 10^{17} \mathrm{n} \cdot \mathrm{cm}^{-2} \cdot \mathrm{sec}^{-1}$. The first two irradiation's were made with a pneumatic transfer system that had a transport time of $6 \mathrm{sec}^{7}$ Activity measurements were done by $\mathrm{Ge}(\mathrm{Li}) \gamma$-ray spectroscopy without chemical separations after the first two irradiations and with chemical separations after the third irradiation; in the latter case a well-type $\mathrm{Ge}(\mathrm{Li})$-detector was used for enhanced efficiency.

All spectra were stored on magnetic tape and analyzed on a CDC 6600/6700computer. The program ${ }^{8,9}$ locates statistically significant peaks, fits a modified Gaussian function to the peaks and calculates the mass of the target elements by comparison to a standard. The standards were made of $\mathrm{NH}_{4} \mathrm{NO}_{3}$ to which the elements of interest were added, and thus were identical to the samples as far as 


\section{A. WYTTENBACH et a1.: DETERMINATION OF IMPURITIES}

Table 1

Irradiation and measuring conditions

\begin{tabular}{|c|c|c|c|c|c|c|c|}
\hline $\begin{array}{l}\text { Irradia- } \\
\text { tion } \\
\text { time }\end{array}$ & Decay & Measuring & Nuclide & Half-life & $\begin{array}{c}\gamma \text {-line } \\
\text { used, } \\
\text { keV }\end{array}$ & $\begin{array}{l}\text { Determination } \\
\quad \text { limit, } \mu \mathrm{g}\end{array}$ & \\
\hline \multirow[t]{2}{*}{$5 \mathrm{~m}$} & \multirow[t]{2}{*}{$1.5 \mathrm{~m}$} & \multirow[t]{2}{*}{$2.5 \mathrm{~m}$} & ${ }^{28} \mathrm{Al}$ & \multirow{2}{*}{$\begin{array}{l}2.25 \mathrm{~m} \\
3.71 \mathrm{~m}\end{array}$} & 1779 & $3 \cdot 10^{-2}$ & \\
\hline & & & ${ }^{52} \mathrm{~V}$ & & 1434 & $1 \cdot 10^{-3}$ & .ี \\
\hline \multirow[t]{7}{*}{$12 \mathrm{~m}$} & $4.5 \mathrm{~m}$ & $4 \mathrm{~m}$ & ${ }^{49} \mathrm{Ca}$ & $8.76 \mathrm{~m}$ & 3084 & 2 & $\tilde{z}$ \\
\hline & \multirow[t]{3}{*}{$50 \mathrm{~m}$} & \multirow[t]{3}{*}{$10 \mathrm{~m}$} & ${ }^{38} \mathrm{Cl}$ & 37 & 1642 & $3 \cdot 10^{-1}$ & 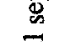 \\
\hline & & & ${ }^{56} \mathrm{Mn}$ & 155 & 847 & $1 \cdot 10^{-3}$ & 吾 \\
\hline & & & $116 \mathrm{~m}$ In & $54 \quad \mathrm{~m}$ & 1097 & $1 \cdot 10^{-4}$ & 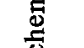 \\
\hline & \multirow[t]{3}{*}{$6 \mathrm{~h}$} & \multirow[t]{3}{*}{$10 \mathrm{~m}$} & ${ }^{24} \mathrm{Na}$ & $15.0 \mathrm{~h}$ & 1368 & $4 \cdot 10^{-2}$ & 울 \\
\hline & & & ${ }^{42} \mathrm{~K}$ & $12.4 \mathrm{~h}$ & 1525 & & \multirow{15}{*}{ 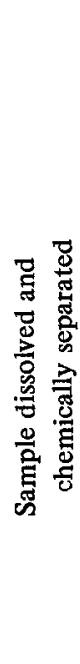 } \\
\hline & & & ${ }^{82} \mathrm{Br}$ & $35.3 \mathrm{~h}$ & 554 & $4 \cdot 10^{-2}$ & \\
\hline \multirow[t]{13}{*}{$510 \mathrm{~m}$} & $14 \mathrm{~h}$ & $10 \mathrm{~m}$ & ${ }^{64} \mathrm{Cu}$ & $12.8 \mathrm{~h}$ & 511 & $1 \cdot 10^{-3}$ & \\
\hline & \multirow[t]{4}{*}{$45 \mathrm{~h}$} & \multirow[t]{4}{*}{$3 \mathrm{~h}$} & ${ }^{65} \mathrm{Zn}$ & $245 \quad \mathrm{~d}$ & 1115 & $2 \cdot 10^{-2}$ & \\
\hline & & & $69 \mathrm{~m}_{\mathrm{Zn}}$ & 14 & 439 & $4 \cdot 10^{-3}$ & \\
\hline & & & $99 \mathrm{~m} \mathrm{Mo}$ & 67 & 140 & $1 \cdot 10^{-3}$ & \\
\hline & & & ${ }^{115} \mathrm{Cd}$ & 54 & 336 & $3 \cdot 10^{-3}$ & \\
\hline & $16 \mathrm{~h}$ & $1 \mathrm{~h}$ & ${ }^{76} \mathrm{As}$ & 26 & 559 & $1 \cdot 10^{-4}$ & \\
\hline & & & ${ }^{122} \mathrm{Sb}$ & 67 & 564 & $5 \cdot 10^{-5}$ & \\
\hline & $60 \mathrm{~h}$ & $5 \mathrm{~h}$ & ${ }^{59} \mathrm{Fe}$ & 45 & 1099 & $2 \cdot 10^{-1}$ & \\
\hline & & & ${ }^{60} \mathrm{Co}$ & 53 & 1332 & $1 \cdot 10^{-4}$ & \\
\hline & \multirow[t]{4}{*}{$70 \mathrm{~h}$} & \multirow[t]{4}{*}{$4 \mathrm{~h}$} & ${ }^{46} \mathrm{Sc}$ & 84 & 889 & $4 \cdot 10^{-5}$ & \\
\hline & & & $14^{\circ} \mathrm{La}$ & 40 & 487 & $4 \cdot 10^{-5}$ & \\
\hline & & & $152 \mathrm{~m}_{\mathrm{Eu}}$ & 9 & 122 & $4 \cdot 10^{-5}$ & \\
\hline & & & ${ }^{15{ }^{3}} \mathrm{Sm}$ & 47 & 103 & $2 \cdot 10^{-5}$ & \\
\hline
\end{tabular}

matrix and geometry are concerned. The data pertinent to activation and measurement are given in Table 1; detection limits given are those calculated for an ice sample of mean composition.

The chemical separation after the third irradiation is mainly based on the quantitative and selective extraction of groups of elements with different metal-dithiocarbamates as reagents. ${ }^{1-12}$ The sample is dissolved in $5 \mathrm{~N} \mathrm{HClO}_{4}$ with the addition of $50 \mu \mathrm{g}$ of the appropriate carriers and heated until it reached a temperature of $200{ }^{\circ} \mathrm{C}$. The solution is then brought to $\mathrm{pH} 1$ and subjected to several extraction steps (Table 2). Every element considered is extracted to better than $98 \%$ in a single extraction with the exception of $\mathrm{Zn}$. $\mathrm{Zn}$ is distributed between fraction 2 
A. WYTTENBACH et al.: DETERMINATION OF IMPURITIES

Table 2

Sequence of extractions

\begin{tabular}{|c|c|c|c|c|c|}
\hline $\begin{array}{l}\text { Extrac- } \\
\text { tion } \\
\text { number }\end{array}$ & $\begin{array}{l}\text { Condition of } \\
\text { aqueous phase }\end{array}$ & Reagent $^{a}$ & Concentration & $\begin{array}{l}\text { Extrac- } \\
\text { tion } \\
\text { time }\end{array}$ & $\begin{array}{l}\text { Elements observed } \\
\text { regularly in ice } \\
\text { samples }\end{array}$ \\
\hline 1 & $\mathrm{HClO}_{4}$, pH 1 & $\mathrm{Bi}(\mathrm{DDC})_{3}$ & $2 \cdot 10^{-3} \mathrm{M}$ in $\mathrm{CHCl}_{3}$ & $5 \mathrm{~m}$ & $\mathrm{Cu}$ \\
\hline 2 & $\mathrm{HClO}_{4}, \mathrm{pH} 1$ & $\mathrm{Zn}(\mathrm{DDC})_{2}$ & $2 \cdot 10^{-3} \mathrm{M}$ in $\mathrm{CHCl}_{3}$ & $2 \mathrm{~m}$ & $\mathrm{Cd}, \mathrm{Mo} ; \mathrm{Zn}(30 \%)$ \\
\hline 3 & $\begin{array}{l}\text { reduced with } \mathrm{KI} \text { and } \\
\text { ascorbic acid. } 1 \mathrm{~N} \text { in } \\
\mathrm{HCl}\end{array}$ & $\mathrm{Zn}(\mathrm{DDC})_{2}$ & $2 \cdot 10^{-3} \mathrm{M}$ in $\mathrm{CHCl}_{3}$ & $2 \mathrm{~m}$ & $\mathrm{As}, \mathrm{Sb}$ \\
\hline 4 & citrate buffer, $p H 5$ & $\mathrm{NH}_{4} \mathrm{DDC}$ & $2 \cdot 10^{-3} \mathrm{M}$ in $\mathrm{CHCl}_{3}$ & $5 \mathrm{~m}$ & $\mathrm{Fe}, \mathrm{Co} ; \mathrm{Zn}(70 \%)$ \\
\hline 5 & pH 2 & HDEHP & $25 \%$ in toluene & $5 \mathrm{~m}$ & $\mathrm{Sc}, \mathrm{La}, \mathrm{Sm}, \mathrm{Eu}$ \\
\hline
\end{tabular}

${ }^{a}$ DDC: diethyldithiocarbamate, HDEHP: bis (2-ethylhexyl) orthophosphoric acid.

${ }^{b}$ Unless otherwise noted, extraction for a given element is $>98 \%$.

(ca. $30 \%$ ) and fraction 4 (ca. $70 \%$ ); its total recovery however is $0.98 \pm 0.01$. The organic extracts have a volume of $30 \mathrm{ml}$ and are evaporated to $3 \mathrm{ml}$ before counting. It was ascertained that this evaporation step entails no loss of activity. Four samples and two standards can be handled by one man in $5 \mathrm{hrs}$.

The chemical separation outlined above, while necessitating some work, had the following beneficial effects on the analysis:

(1) the decontamination from ${ }^{24} \mathrm{Na}$ and ${ }^{82} \mathrm{Br}$ was better than $10^{4}$, thus eliminating difficulties with large Compton backgrounds and allowing measurement very soon after activation.

(2) Splitting up the different activities into several groups diminished the possibility that one dominant activity will greatly reduce the sensitivity for all other activities; noteworthy in this respect is the great amount of ${ }^{64} \mathrm{Cu}$ which is removed by the first extraction.

(3) The assignment of a $\gamma$-line to a specific nuclide can be made without any further checks (such as additional lines or decay curves), since most ambiguities can be ruled out by considering the chemical properties.

\section{Blanks and reproducibility}

The blank values for the carrier material $\mathrm{NH}_{4} \mathrm{NO}_{3}$, for the filters and for the irradiation container are given in Table 3. When comparing these values to the values found in ice, which are also given in Table 3, it can be seen that the highest blanks are in general contributed by the filters. Separate experiments were therefore done to determine how much is washed out from the filters by filtering 
A. WYTTENBACH et al.: DETERMINATION OF IMPURITIES

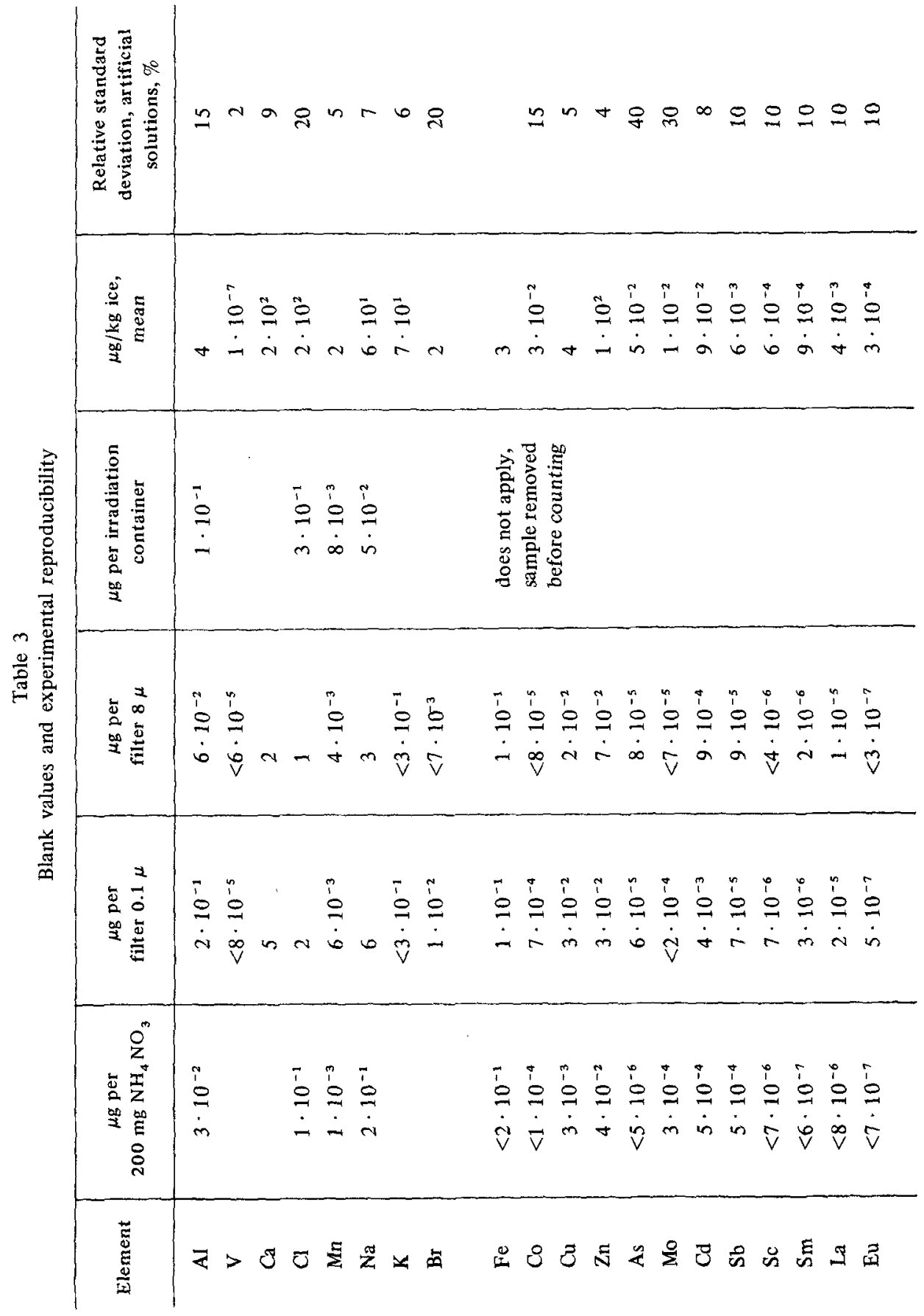




\section{A. WYTTENBACH et al.: DETERMINATION OF IMPURITIES}

$500 \mathrm{ml}$ of water. It was found that $(3.8 \pm 1.8) \mu \mathrm{g} \mathrm{Na},(2 \pm 0.5) \mu \mathrm{g} \mathrm{Ca}$ and no $\mathrm{Al}$, $\mathrm{Cl}$ or $\mathrm{Mn}$ is washed out. Thus the contribution by the filters to the blank is substantial for $\mathrm{Na}$ and negligible for $\mathrm{Ca}, \mathrm{Al}, \mathrm{Cl}$ and $\mathrm{Mn}$. All results have been corrected for these blank contributions.

The reproducibility of the determination were checked by analyzing several aliquots (usually more than 6) of artificial aqueous solutions that contained the elements to be determined in concentrations equal to the mean concentration found in the ice samples. These results are also given in Table 3. The observed relative standard deviation is in most cases larger than is to be expected from counting statistics, from the variation in the recovery of the freeze-drying process and from the recovery of the chemical separations. The experimental coefficient of variation must therefore contain some contribution from blank problems.

\section{Results}

A full discussion of the results exceeds the scope of this communication and will appear elsewhere. ${ }^{13}$ However a few of the findings will be discussed here.

\section{Analysis of the material on the filters}

All filters have been analyzed non-destructively by neutron activation after filtration of the melted ice. The results (filter blanks subtracted) are given in Table 4. It is immediately clear that the filters do contain substantial amounts of material (column b). This was no surprise but deserves stressing in view of the fact that

Table 4

Analysis of the material on the filters

\begin{tabular}{c|c|c|c}
\hline (a) & (b) & (c) & (d) \\
\hline Element & $\begin{array}{c}\mu \text { on both filters } \\
\text { (mean of } \\
13 \text { sections) }\end{array}$ & $\frac{\mu \text { g on filters }}{\mu \text { in filtered water }}$ & $\frac{8 \mu \text { filter }}{\text { both filters }}$ \\
\hline $\mathrm{Al}$ & $1.6 \cdot 10^{1}$ & 10 & 0.9 \\
$\mathrm{~V}$ & $2.2 \cdot 10^{-2}$ & 3.1 & 0.8 \\
$\mathrm{Mn}$ & $1.6 \cdot 10^{-1}$ & 0.16 & 0.8 \\
$\mathrm{~K}$ & 6.2 & 0.12 & 0.8 \\
$\mathrm{Cl}$ & 4.6 & 0.03 & 0.5 \\
$\mathrm{Ca}$ & $\lesssim 5.4$ & $\leq 0.06$ & $\geq 0.6$ \\
$\mathrm{Na}$ & 1.2 & 0.04 & 1.0
\end{tabular}


A. WYTTENBACH et al.: DETERMINATION OF IMPURITIES

Table 5

Mean concentration $(\mu \mathrm{g} / \mathrm{kg})$ in ice and rain

\begin{tabular}{l|c|c|c|c}
\hline Element & $\begin{array}{c}\text { Ice Jungfraujoch } \\
\text { present work }\end{array}$ & $\begin{array}{c}\text { Ice } \\
\text { Mont Blanc }\end{array}$ & $\begin{array}{c}\text { Ice } \\
\text { Greenland }^{14}\end{array}$ & Rain England $^{5}$ \\
\hline $\mathrm{Al}$ & $3.4 \pm 2.6$ & 110 & 3.3 & 4.8 \\
$\mathrm{~V}$ & $(1.4 \pm 0.6) \cdot 10^{-2}$ & & & 1.2 \\
$\mathrm{Ca}$ & $190 \pm 90$ & 7 & 4.8 & $<1000$ \\
$\mathrm{Cl}$ & $170 \pm 85$ & 101 & 2400 \\
$\mathrm{Mn}$ & $2.0 \pm 1.0$ & 1.7 & 2.2 & 2 \\
$\mathrm{~K}$ & $104 \pm 155$ & 56 & 12.9 & 1340 \\
$\mathrm{Na}$ & $52 \pm 20$ & 69 & 39 \\
$\mathrm{Br}$ & $2 \pm 1$ & & & 22 \\
$\mathrm{Sc}$ & $(5.7 \pm 2.5) \cdot 10^{-4}$ & 54 & & $1.6 \cdot 10^{-1}$ \\
$\mathrm{Fe}$ & $1.9 \pm 0.7$ & & & $<0.3$ \\
$\mathrm{Co}$ & $(2.7 \pm 1.0) \cdot 10^{-2}$ & & & $7.8 \cdot 10^{-2}$ \\
$\mathrm{Cu}$ & $3.7 \pm 10.7$ & & \\
$\mathrm{As}$ & $(5.7 \pm 4.2) \cdot 10^{-2}$ & & & \\
$\mathrm{Sb}$ & $(5.8 \pm 4.1) \cdot 10^{-3}$ & & & \\
$\mathrm{Mo}$ & $(1.2 \pm 1.2) \cdot 10^{-2}$ & & & \\
$\mathrm{Cd}$ & $(8.6 \pm 5.6) \cdot 10^{-2}$ & & & \\
$\mathrm{Sm}$ & $(8.6 \pm 4.9) \cdot 10^{-4}$ & & & \\
$\mathrm{La}$ & $(3.6 \pm 1.7) \cdot 10^{-3}$ & & & \\
$\mathrm{Eu}$ & $(2.5 \pm 1.4) \cdot 10^{-4}$ & & & \\
& & & &
\end{tabular}

many previous investigators who performed ice, snow or water analyses explicitly omitted any filtration or centrifugation step; ${ }^{\mathbf{1 , 3 , 4}}$ it also casts some doubt on the validity of the practice of acidifying samples before filtration. When the amount retained on the filters is compared to the amount in solution (column c), the elements are seen to clearly fall into three categories: $\mathrm{Al}$ and $\mathrm{V}$ are much more abundant on the filters than in solution; $\mathrm{Mn}$ and $\mathrm{K}$ are predominantly in solution, and $\mathrm{Cl}, \mathrm{Na}$ and $\mathrm{Ca}$ are almost exclusively in solution. It is further seen that the majority of the solid material is retained on the $8 \mu \mathrm{m}$ filter (column d). Examination of the filters by scanning electron microprobe revealed particles of uniform appearance with $\mathrm{Ca}$ as the major element and conglomerate particles with lines due to $\mathrm{Al}$ and Si. It is sought that these particles are stone dust blown by wind from limestone and from granite rock formations, both of which are present within $500 \mathrm{~m}$ from the drilling place. This conclusion is supported by the ratios of $\mathrm{Al}, \mathrm{V}, \mathrm{Mn}$ and $\mathrm{K}$ on the filters, which are roughly the ones expected for a granite. 


\section{A. WYTTENBACH et al.: DETERMINATION OF IMPURITIES}

Analysis of the filtered melt water

The mean results of 18 sections from the ice core are given in Table 5 together with typical values of rain and of ice from Greenland and from Mont Blanc. Pending further statistical evaluation, only the following points can be noted here:

- The standard deviation of the sections relative to their mean in much larger than the standard deviation found for artificial solutions of comparable concentrations. However many elements are positively intercorrelated, and a similar anomalous fluctuation is noted for the ${ }^{3} \mathrm{H}$-content at the same location. ${ }^{2}$ It is thus thought that the section to section variation is real; the reason for this remains open.

- Most concentration found at Jungfraujoch are intermediate between Greenland ice and English rain.

- $\mathrm{Na}$ and $\mathrm{Cl}$ seem to be largely of maritime origin. The $\mathrm{Cl} / \mathrm{Na}$ ratio is $3 \pm 1$, which is somewhat larger than the 1.8 valid for seawater. Values as high as 14 have been found in Antarctica. ${ }^{3}$

- Ca seems to derive from soil dust. While the values for $\mathrm{Cl}, \mathrm{Na}, \mathrm{K}$ and $\mathrm{Mn}$ in the ice from Col du Midi in the Mont Blanc ${ }^{3}$ roughly coincide with our values from Jungfraujoch, we do find 30 times more $\mathrm{Ca}$ in the latter place. This could be attributed to the presence of limestone formations within $500 \mathrm{~m}$ from the Jungfraujoch, while there are no such formations within $10 \mathrm{~km}$ from Col du Midi. The fact that most of the $\mathrm{Ca}$ is found in the meltwater must be due to its dissolution by carbonic acid.

- The $\mathrm{Br} / \mathrm{Cl}$ ratio is 6 times larger than the value expected from seawater alone. $\mathrm{Br}$ could possibly be of anthropogenetic origin.

\section{References}

1. M. MUROZUMI, T.J. CHOW, C. PATTERSON, Geochim. Cosmochim. Acta, 33 (1969) 1247.

2. U. SCHOTTERER, (unpublished results).

3. M. BRIAT, Publication 166 du Laboratoire de Glaciologie du Centre National de la Recherche Scientifique, Grenoble, 1974.

4. B. SALBU, E. STEINNES, A.C. PAPPAS, Anal. Chem., 47 (1975) 1011.

5. L. SALMON, AERE-R 7859, 1975.

6. S.H. HARISSON, P.D. LAFLEUR, W.H. ZOLLER, Anal. Chem., 47 (1975) 1685.

7. A. WYTTENBACH, Helv. Chim. Acta, 52 (1969) 2458.

8. P.A. SCHUBIGER, S. CHAKRABORTY, A. WYTTENBACH, W. BLASER, J. Radioanal. Chem., 25 (1975) 141.

9. S. CHAKRABORTY, A. SCHUBIGER, A. WYTTENBACH, Intern. Rep., TM-CH-143, Swiss Federal Reactor Institute, 1975.

10. A. WYTTENBACK, S. BAJO, Anal. Chem., 47 (1975) 2.

11. A. WYTTENBACH, S. BAJO, Anal. Chem., 47 (1975) 1813.

12. S. BAJO, A. WYTTENBACH, Anal Chem., 48 (1976) 902.

13. R. RAUTER, Thesis, University of Zürich 1977, EIR-Bericht 313, 1977.

14. J.H. CRAGIN, M.M. HERRON, C.C. LANGWAY, Research Rep. 341, Cold Regions Research and Engineering Laboratory, 1975. 